\title{
The Missing Links: Towards the Effective Management and Control of Corruption in Nigeria, Africa and the Global South
}

\author{
Ethelbert Okey Lawrence
}

\author{
Department of Sociology, University of Jos, PMB 2084, Plateau State, Nigeria
}

\begin{abstract}
Corruption has become a full blown cancer in Nigeria, Africa and other Global South countries, consequently bringing about economic backwardness, political instability, social insecurity, infrastructural decay, unaccountability, negation of the principle of law, etc. Efforts towards curbing it have failed woefully. It is evident that there are missing links towards effective management and control of the phenomenon in these areas. Based on secondary data, and using Nigeria as sample, this paper examined these missing links towards effective management and control of the phenomenon. Since corruption is multi-faceted i.e. manifests through multiplicity of factors ranging from ethno-religious, and sectional sentiments on one hand, and on the other, reflected in the social classes of active, and non-active players of the phenomenon; as well as international factors sustaining the menace; not leaving the mechanisms for control and management of the whole process of its prevalence. Thus, an integrative theoretical approach was used to explain these missing links which have been identified as corrupt individuals in the corridors of power; defective/imbalance of political and social structure; legal justice; social justice; and international collaboration. Findings reveal: political powers in the hands of corrupt individuals; poor implementation of legal and social justice among others account for the persistence of corruption in these areas. Some of the recommendations include: having individuals with proven records of integrity vie for political elective positions; there should be no sacred cows in the fight against corruption; and, there should be a redefinition of the core values to define corruption.
\end{abstract}

Keywords: Corruption, Public Corruption, control, effective management, Global South, Africa, Nigeria.

\section{INTRODUCTION}

Corruption is a global problem with negative consequences on the general wellbeing of society (socio-political and economic). The history of its emergence cannot be absolutely tied to a particular society; hence, it is inherent in all human societies and virtually wherever humans converge in varying degrees. Efforts have been made and are still being made towards reducing the menace yet, it persists with new forms each passing day. This paper examines the missing links towards effective management and control of corruption in the Global South countries (using Nigeria as the microscope due to the fact that the socio-political and economic dynamics which makes corruption thrive in the Global South are found in it in varying degrees) given the fact that the area has consistently been conceived as safe-haven for its occurrence as evident in transparency international rating over the years. To achieve this, the paper is divided into six sections consisting of background; extent of corruption; effects of corruption; responses to corruption in the Global South; the missing links towards effective management and control of corruption in Nigeria, Africa and several Global South countries; and recommendations.

\footnotetext{
*Address correspondence to this author at the Department of Sociology, University of Jos, PMB 2084, Plateau State, Nigeria;

E-mail: ethelbertlawrence@yahoo.com
}

\section{BACKGROUND}

Public corruption refers to acts/actions exhibited by public officials who negate the basic ethics of the office or position held. It is the illegitimate, illegal, or misuse of fiduciary position and influence to acquire benefit(s) for oneself and cronies which negates the principles of the rule of law. Corruption is manifested in various ways and in varying degrees in different countries of the world (both the Global North and South). Some of the ways it manifests include: placement of one's interest above the demands of individual's duties or responsibilities; use of one's office or position for pecuniary advantages; receiving and offering of gratification; influence peddling; insincerity in advice with the aim of gaining advantages; less than a full day's work for a full day's pay; tardiness and slovenliness; embezzlement; bribery; contract scam; money laundering; advanced fee fraud; tax evasion; nepotism; ethnocentrism; kickbacks; forgery; dude cheques etc., (Ribadu, 2004:4; Constitution of the Federal Republic of Nigeria 1999: $5^{\text {th }}$ schedule; ICPC Act 2000; Criminal Code CAP 'C38'p256a; Igwe, 2010: 101-103). Due to widespread corruption globally, the Transparency International ( $\mathrm{TI}$ ) was established in May 1993 through the initiative of Peter Elgen, a former regional director of the World Bank, as a global nongovernmental organization which surveys and publishes corporate and political corruption in many countries. This organization publishes a Corruption Perception Index (CPI) annually that rate countries on the basis of perceived corruption in the system. 
Another response to corruption in the present global system is the Organization for Economic Cooperation and Development (OECD), through an anti-bribery Convention which was signed on 17 December 1997 and came into force on 15 February 1999. The aim and objective of this convention is to reduce corruption in developing countries by encouraging the enforcement of sanctions against bribery in international business activities by companies based in the convention member nations. This is aimed at creating a level playing ground in modern international business environment. Expectedly, signatories to the Convention are required to put in place legal framework that criminalizes the act of bribing foreign public official(s). Regrettably, the OECD lacks the authority to implement the convention, but reduces or limits its authority to monitoring the implementation of the Convention by member countries. Therefore, it is the responsibility of member nations to implement laws and regulations in accordance with the demand of the Convention.

However, what appears to be a more comprehensive response to public corruption globally is the United Nations Convention against Corruption which was adopted on October 31, 2003, by the United Nations General Assembly at the UN's Headquarters in New York and signed on $9^{\text {th }}$ December 2003, at Merida, Yucatan (Mexico). The Convention becomes effective on $14^{\text {th }}$ December 2005 , having been ratified by 30 countries, 140 signatories and 160 parties. This convention is the first legally binding international anticorruption instrument consisting of 8 chapters and 71 articles, basically seeking for cooperation among and between member nations to effectively tackle corruption globally. Specifically, the UK in August of 2015 established the International Corruption Unit (ICU) under the UK National Crime Agency (NCA) to investigate the bribery of foreign officials as well as money laundering by corrupt foreign official (especially those from the Global South) and their associates; trace and recover these sleaze wealth; as well as assist foreign anti-graft agencies in investigating corruption incidences involving their citizens especially in the UK. This is aimed at making the UK unsafe for these corrupt individuals. However the ICU acts on the basis of information provided to it by the foreign government(s) and the NCA. Unfortunately the phenomenon of corruption seems to have defiled all odds in the Global South and Nigeria in particular.

\section{THE EXTENT OF CORRUPTION}

Over the years, Nigeria, Africa, and indeed several Global-South countries have been categorized as safe havens for corruption as revealed by TI rankings. For example, of the 31 countries surveyed from the Americas in 2014, Haiti, and Venezuela secured 1.9 out of 10 points each thus occupying $161^{\text {st }}$ position out of 175 countries surveyed; Paraguay scored 2.4 out of 10 points; Nicaragua obtained 2.8 out of 10 points, placing 133 on the global rating. Honduras secured 2.9 points. Guyana scored 3.0 points. Guatemala and Dominican Republic got 3.2 points each. Ecuador, Argentina, and Mexico secured 3.3, 3.4, and 3.5 respectively. Though Mexico performed better than some of the countries in the Americas, it is conceived as one of the most corrupt countries in 2014. With incidences of corruption in virtually all sectors of the society i.e. in politics, government, the financial sector etc. having also ranked very low by the OECD for the same period. Singapore was rated best in Asia with 8.4 out of 10 points. Others like: India and the Philippines scored 3.8 out of 10 points each; Indonesia obtained 3.4 out of 10 points; while Tajikistan secured 2.3 out of 10points constituting part of the most corrupt countries in Asia. Of countries surveyed in Africa, Botswana ranked best with 6.3 out of 10 points occupying the 31 position on the global scale, Cape Verde 5.7 out of 10 points thus sitting on the 42 position, Seychelles 5.5 out of 10 points. While countries like Somalia with 0.8 out of 10 points, the Sudan with 1.1 out of 10 points, South Sudan which secured 1.5 out of 10 points, Eritrea and Libya with 1.8 out of 10 points each, Guinea-Bissau and Angola both with 1.9 out of 10 points were reported among the most corrupt nations in Africa. On the global scale, Eritrea, Libya, Uzbekistan, Turkmenistan, Iraq, South-Sudan, Afghanistan, Sudan, North-Korea, and Somalia constitute the 10 most corrupt nations in 2014. Specifically, Nigeria has been classified as one of the most corrupt countries in the world. This is evident in its ranking by the Transparency International in 1996, 1997 and 2000, as the most corrupt country in the world, the second most corrupt nation in the world in 1999, 2001, 2002 and 2003; the third most corrupt nation in 2004 and 2005; the fourth most corrupt nation in 1998; and the fifth most corrupt nation in 2006. In 2007, Nigeria was ranked 147 out of 180 countries surveyed, with 2.2 points out of 10 ; in 2008, the country was ranked 121 out of 180 countries surveyed making it the $59^{\text {th }}$ most corrupt nation, with 2.7 points out 10; in 2009, she was ranked 130 out of 180 surveyed countries, scoring 2.5 points over 10; while in 2010 and 2011, Nigeria was ranked 135 out of 178 surveyed countries with 2.4 points, and 143 out of 183 surveyed countries scoring 2.4 points over 10 respectively (Enweremadu, 2011:10; 
Transparency International, 2012). In 2012, the country was ranked $139^{\text {th }}$ out of 176 countries thus becoming the $35^{\text {th }}$ most corrupt country in 2012 with 2.7 points; in 2013 it ranked $136^{\text {th }}$ out of 144 with 2.5 out of 10 points; in 2014, the nation was ranked $136^{\text {th }}$ out of 174 countries surveyed with 2.7 out of 10 points hence making it the $39^{\text {th }}$ most corrupt country (Transparency International, 2014). The prevalence of corruption in Nigeria and the Global South is due to their defective fiscal policies i.e. taxes, debt or borrowing as balancing factors for the development of the economy and by extension the society at large. Simply put that the instruments of fiscal policy which include: taxes and all their associated features like tax exemptions, tax deductions, schedules of rates; mode and procedures of government's expenditures which include subsidies, payment transfers, grants/relief payments to pioneer industries, contract awards and various public work projects, as well as capital allowances which are aimed at enhancement of welfare in the economy through sustained improvement in the living standard of the people, are beclouded in secrecy, thus giving rise to high level of malfeasance. The above discussed trend in the prevalence and extent of corruption in the Global South countries may not change significantly for better in the next 25 years except there are positive changes occurring in political leadership style, the societies in general as well as strategies for corruption management in these areas.

\section{THE EFFECTS OF CORRUPTION}

The effects of corruption in Nigeria, Africa, and several Global South countries include, economic backwardness resulting to unemployment and poverty; political instability; social insecurity; infrastructural decay; unaccountability; negation of the principle of law; etc. (Ibrahim, in Odekunle and Lame, 2000; Ikoiwak, 1986; Ejionye and Emereuwaonu, 1986; emphasis mine). Corruption is perverse in these countries due to their weak system of accountability, weak and perverse political system which is manifested through sit-tight public office holders which can best be described as demonarchracy (a system where assumed democratically elected political leaders act as monarchs with absolute powers, hence no check and balance on their activities. No wonder the incidences of individuals holding on to political power for as long as one wills or forced out of office) due largely to weak or poor democratic system, the prevalence of the principle of Machiavellianism, lack of well-established public fund monitoring and evaluation system, lack of patriotism, poor weak civil society, as well as sectionalism, ethnocentrism and religious bigotry. Surely, the effects of corruption can be said to be profound in Nigeria, and indeed Africa and several Global South countries (Ake, 2003; Wilmot, 2005; Igwe, 2010; Mills, in Odekunle \& Lame, 2000; emphasis, mine). This has adversely affected the socio-political and economic conditions of these countries.

Corruption in the body polity of these countries accounts for various forms of violent conflicts. For example: the ethnic conflicts in Rwanda in 1994 which claimed between 800.000 to 1.000 .000 lives; the socioeconomic and political uprising in the Arab world popularly referred to as the Arab-spring from 2010 till date; the political crisis in Kenya (December 2007February 2008); the Nigerian civil war, 1967-1970 and various crisis in the Niger Delta; the Ivorian conflict (2002-2011); the conflict in Central African Republic which become messier in 2015; the overthrow of Blaise Compaore of Burkina Faso in 2015; the conflict in Sierra Leone(1991-2002). Furthermore, corruption scandals have also contributed to the downfall of governments in Ecuador, Brazil and India (Kimberley and Elliot, 2010). All of which can be attributed to seclusion of some from the, and in the allocation of national resources due to corruption. Hence leading to discontent, antagonism and finally into violent conflicts, or unpopularity of incumbents in elections.

The effects of corruption particularly on the general well-being of Nigeria as a nation are enormous, thus hampering the development of the nation (sociopolitical and economic). The phenomenon stigmatizes the image of virtually all past and present governments, affects their integrity, weakens their credibility, and as such reduces the nation to a pariah status in the international community. This has brought a reduction in the effectiveness and efficiency of the developmental programmes and policies which have been formulated (Ikoiwak, 1986:83; Ibrahim in Odekunle and Lame, 2000:17). There exist some features about which scholars have consensus as implications of corruption on Nigeria (by extension several countries in the Global South). These include the weakening of the nation's economy, infrastructural decay, debt burden on the nation, promotion of inertia and lethargy.

Corruption weakens the nation's economy due to the fact that the nation's treasury is subjected to incessant looting by public officials. Consequently, there is prevalence of such corrupt practices like fraud, money laundering, embezzlement etc. which have remained unabated in Nigeria. It is regrettable that from 
independence till date, the country is continuously losing huge sums of money due to the activities of corrupt public office holders. The implication of these immoral action(s) is that the funds required for the growth of the nation's economy are unceremoniously being lost as a result of diverse forms of financially related irregularities. For instance, Madunagu, in (Agedah, 1993:63) reveals that Nigeria, between 1979 and 1983, lost billions of naira to corrupt practices embarked upon by public officers; (Nwadukwu and Alike, 2012:1 \& 6) reveal that apart from the 2.6 trillion loss reported by the Farouk-led committee, the country lost another 442billion naira in 2011 relating to oil subsidy; according to (Umez, 2012:16-17) Crime, corruption, and trade mispricing accounted for 130 billion dollars loss to Nigeria between 2000 and 2009, representing an estimate of 14 billion dollars a year. It is becoming increasingly difficult for one to listen to news of events or read through news contents on news prints (newspapers, magazines etc.) without the report of one corrupt practice or another, so that what has become one of the major articles or commodity for sale-able news in Nigeria is 'corruption'. The above financial loses persists in several countries in the Global South.

The pandemic of corruption has severe negative implications on infrastructural development in Nigeriasame prevails in several Global South countries. This is evident in the abundance of abandoned projects, white elephant projects, contract scam and inflations, ten percent or more for contract awards - which leads to non-execution or poor execution of projects, nonprovision of educational facilities, health facilities, and other social amenities (water, electricity, transportation, etc), due to diversion of funds and other resources meant for social and economic viable projects to private pockets or those of cronies (Wilmot, 2005:111; lgwe, 2010:96). The immediate outcome of lack of infrastructural development brought about by lack of resources due to corruption is that human capital development which ought to bring about the development of the nation in general (socio-political and economic) is hampered. Hence stagnation and dedevelopment sets in, which are quickly manifested through infrastructural decay, social and political insecurity, as well as economic backwardness, and ultimately, to poverty, leading to mass economic migration to the Global North through whatever means for greener pastures and non-economic migration for safety and security. (The prevailing migration crises in Europe 2014-2015 and upwards as the case may be, are responses to the issues discussed above).
The effects of corruption run deeper than one could imagine. It places severe burden of debt (both internal and external) on these countries. Madunagu, in (Agedah, 1993:69) reveals that corruption and profligacy of the second republic politicians in Nigeria accounts for the shoot up of the country's external debts which sky-rocketed to 12 billion dollars - an increase of about 200 percent in less than four years. In like manner, successive administrations could not remedy the external debt burden but helped in making the condition worse. Hence, inflation became prevalent in the country (Odekunle and Lame, 2000:63) posit that corruption creates gaping hole in government finances, promotes borrowing at high interest rate, makes inflation soar and weakens the purchasing power of the currency and as such affects the honest wage earner whom (Agedah, 1993:69) refers to as "the popular masses" who bears the brunt of these burdens due to the prevalence of gaping hole in government finances brought about by various forms of financial irregularities, mismanagement and misappropriation hence, dragging uncountable number of Nigerians into poverty. Nigeria's case was critical till it secured the extraordinary 18 billion dollars debt forgiveness from the Paris Club in 2005, and the subsequent payment of 12 billion dollars to upset the outstanding. Today, events in the Global South areas reveal that both internal and external debts as well as inflation have greatly hampered development in these countries dragging so many of its citizens into poverty.

Furthermore, corruption promotes inertia and lethargy in the system but worse of all is the fact that it engenders and promotes unaccountability which is the safe haven for the actor(s) comfort and security. With reference to Nigeria, "Babangida's administration, could not properly account for the additional 12.4 billion dollars from oil sales that Nigeria earned during the gulf war"; Mohammed Abacha could not offer a good account of about 700 million dollars which he claimed that his late father General Sani Abacha gave him (Mohammed) for safe keeping in his (Mohammed's) home. (Odekunle and Lame, 2000:63).; the inability of Anastasia Nwaobi to explain to the House of Representative Ad-hoc Committee on Nonimplementation of Capital Expenditure how 221.1 billion naira said to have been spent on fuel subsidy between January and July 2015 was secured (Yesufu., and Itua, 2015). The fact remains that Nigeria is a nation that shy away from demanding accountability from its past leaders with regards to their stewardship to the nation, coupled with the fact that issues of 
corruption were never handled with shrewdness in the country. No wonder the persistent occurrence of the phenomenon with new patterns evolving each new day. The above prevails in some Global South countries. For example, Carlos Andrés Pérez unpopularity and subsequent removal from office in Venezuela in 1993 can be linked to unaccountability involving 250 million bolivars due to corruption; Thaksin Shinawatra of Thailand was ousted in a military coup in 2006 due to his administration's high level of unaccountability. However, on the return to civil rule in 1999, President Olusegun Obasanjo identified corruption as the major obstacle to the Nigeria's development. The government introduced severe measures to tackle the problem. A major aspect of the Obasanjo's administration's effort to tackle corruption was the establishment of the Independent Corrupt Practices and other related offences Commission (ICPC) in 2000 and the Economic and Financial Crimes Commission (EFCC) in 2003. The EFCC in particular was given special powers to enable it fight corruption and economic crimes. The agency receives tremendous support from foreign governments as well as collaborates with the International Financial Units to combat corruption (Enweremadu, 2011:6, 8; Ibrahim in (Odekunle and Lame, 2000:81; emphasis, mine). However, corruption continues to dominate public discourse in the country and regarded by many as an intractable problem hindering political stability and economic development. This is so due to the fact that in spite of efforts being made by the bodies charged with the control of corruption in Nigeria, the menace has persisted. For instance, the EFCC received about 5,400 petitions of corruption between 2003 and 2011, while the ICPC received about 1,846 petitions between 2000 and 2011 , giving a total of about 7,246 reported cases of corruption within the period out of which about 349 number of cases were prosecuted as at 2008 by the two agencies, while the EFCC alone has secured about 650 convictions between 2008 and 2011. This brings us to responses towards management and control of corruption in Nigeria, Africa and several Global South countries.

\section{RESPONSES TO CORRUPTION IN THE GLOBAL SOUTH}

Corruption as a concept and its negative impact on these nations is not something new. Hence the desire of various administrations in tackling it in way(s) believed would yield result(s). A good number of leaders in the Global South have identified the prevalence of corruption in their domains. These include: Najib Razak of Malaysia; Carlos Andrés Pérez of Venezuela; Salva Kirr of South Sudan. Virtually all the military takeovers in Nigeria (Kaduna Nzeogwu, January 1966; Murtala Mohammed, 1975; Muhammadu Buhari, December 1983; Ibrahim Babangida, August 1985) points to corruption in the body polity as reasons for their intervention in government. Correspondingly virtually all administrations in Nigeria point to the prevalence of corruption in the country as a major factor to the nation's socio-political and economic development. For instance, Major Chukwuma Kaduna Nzeogwu while announcing the first military coup in Nigeria stated that:

our enemies are the political profiteers, swindlers, the men in high and low places that seek bribes and demand ten percent; those that seek to keep the country divided permanently so that they can remain in office as ministers or VIPs at least, the tribalists, the nepotists, those that make the country look big for nothing before international circles, those that have corrupted our society and put the Nigerian political calendar back by their words and deeds.

A follow up broadcast by Ironsi on 28 January, 1966 states that "the federal government will stamp out corruption and dishonesty in our public life with ruthless efficiency and restore integrity and self-respect in our public affairs." (Agedah, 1993: 13-14). In like manner, while announcing the military takeover from the civilian regime of Alhaji Shehu Shagari on the 31, December 1983' Brigadier Sani Abacha stated that:

...you are all living witnesses to the great economic predicament and uncertainty, which an inept and corrupt leadership has imposed on our beloved nation for the past four years...our economy, has been hopelessly mismanaged. We have become a debtor and beggar nation---yet our leaders revel in squander mania, corruption and indiscipline, and continue to proliferate public appointments in complete disregard of our stark economic realities.

Major General Muhammadu Buhari the head of the new regime in a subsequent broadcast to the nation stated that: 
...while corruption and indiscipline has been associated with our state of underdevelopment, these two evils in our body politic have attained unprecedented height in the past few years. The corrupt, inept and insensitive leaders in the last four years have been the source of immorality and impropriety in our society. Since what happens in any society is largely a reflection of the leadership of that society, we deplore corruption in all its facets. This government will not tolerate kick-backs, inflation of contracts and overinvoicing of imports etc. Nor will it condone forgery, fraud, embezzlement, misuse and abuse of office and illegal dealings in foreign exchange and smuggling....corrupt officials and their agents will be brought to book. (ibid)

Obasanjo's inaugural speech on May, $29^{\text {th }} 1999$ reveals that:

Corruption, the greatest single bane of our society today, will be tackled head-on at all levels. Corruption is incipient in all human societies and in most human activities, but it must not be condoned...no society can achieve anything near its full potential if it allows corruption to become full-blown cancer it has become in Nigeria. (ibid)

Similarly, Goodluck Jonathan in 2011 states that if we must survive as a nation, there would be no sacred cow as far as corruption is concerned. While (Rodney, 1972), accused Europe of under-developing Africa and several Global South countries through colonialism, events in the post-colonial Africa and most Global South countries point to the fact that political leaders and indeed citizens of these countries as responsible for the said underdevelopment through various corrupt practices (Igwe, 2010).

The appalling socio-political and economic condition of Ghana due to corruption conditioned the cleansing activities of Jerry Rawlings between (1979-1981), the mass action which led to the overthrow of Blaise Compoare of Burkina Faso in 2015 was linked to poor socio-political and economic atmosphere brought about by corruption. In efforts to combat corruption in their countries, various anti-corruption agencies were set up at one time or the other. For example, Corrupt
Practices Investigation Bureau of Singapore (1952); the Commission of Human Rights and Administrative Justice (1993) and the Serious Fraud Office (1998) of Ghana; Oficina Anticorrupción (December, 1999) in Argentina; Corruption Eradication Commission of Indonesia (2002); Anti-Corruption Commission Bangladesh (February, 2004); the Liberian AntiCorruption Commission established (August, 2008); Ethics and Anti-corruption Commission of Kenya (September, 2011) just to mention but a few. Specifically, corruption has remained one of the major factors that impede the overall development of Nigeria. As such, various steps aimed at curbing it have been taken by different administrations in response to it. Measures taken against corruption in Nigeria so far-as in several Global South areas include: legal framework (constitutional provision, especially as contained in chapter 2 of the 1999 Nigerian constitution, Criminal Code and the Penal Code which declares certain behaviours as offences either in the Northern or Southern part of the country, as well as specific legislation against corrupt practices); introduction of programmes like the Ethical Revolution of Shagari-led civilian government which is just a passionate appeal to the conscience of the second republic politicians who were grossly immersed in various forms of corruption, (the ethical revolution did not in any way reduce corruption, let alone its elimination in the body polity), the War Against Indiscipline (WAI) of the Muhammadu Buhari led military administration which was launched in March 1984 with the following aims and objectives: eradication of smuggling, embezzlement of public funds, hoarding, armed robbery, cheating, kickbacks, or any manifestation of indiscipline in the country. The WAI crusade was a drastic and ruthless measure against corruption ravaging the country like wild fire. (Regime of Hope, 1984:14-16; Federal Ministry of Information, 1994). This was due largely to the fact that: Nigeria cut an image in the world community as a country where no act of indiscipline would be too despicable to be imagined.

The WAI crusade resulted in the arrest of hundreds of second republic politicians. The crusade was predicted on the principles of leadership by example. This was however negated as some top military officers who were the touch and flag bearers of this anticorruption crusade and their cronies were found to be neck deep in one form of corrupt practice or another including money laundering, drug trafficking, etc. resulting to conflict of interest within the ruling military class at the time. In 1994, the General Sani Abacha-led military government launched the War Against 
Indiscipline and Corruption (WAIC) programme as a measure against the spate of corrupt practices in the country especially within the financial sector which had made many banks insolvent resulting to high losses of depositors' monies; a situation which the Nigerian Deposit Insurance Company (NDIC) which was set up by the NDIC Decree No. 22 of 1988 as special insurer to the banks could not manage. To sanitize the sector as well as the economy and combat corruption in the country, the government enacted the failed Bank (Recovery of debts) and financial malpractices Decree No. 18 of 1994, and the money laundering Decree of 1995. The outcome of the above was the regrettable fact that about $51(42.5 \%)$ out of the 120 banks in Nigeria were found to be distressed and depositors' funds worth billions of naira lost in the process. The insignificant success of the WAIC campaign was based on the ground that it resulted to the indictment and trial of some highly placed Nigerians, recovered substantial sum from culpable persons and jailed some according to the provisions of the failed Bank Decree. One of those affected was Jimi Lawal, Managing Director of Alpha Merchant Bank. However, the WAIC cannot be said to be a successful response to corruption in Nigeria. This is based on the fact that the man at the helm of it, General Sani Abacha, was found to have looted the nation's treasury without remorse or second thought, (Odenuga, in Odekunle and Lame, 2000:63).

This is a typical Nigeria's story of corruption control where leaders like leviathan enunciate policies which they themselves will not obey; thereby adopting the principle of Machiavellianism which they hope would ultimately shield them and their avarice from the populace. The above dishonesty in controlling corruption prevails with several Global South countries' leaders as events have shown. For example, Ghadaffi in Libya; Mubarak in Egypt; Mugabe in Zimbabwe; Idi Amin in Uganda; Blaise Compaore in Burkina Faso; Ben Ali in Tunisia; Pieta Botha in South Africa; Mobutu Sese Seko of Zaire (now DR Congo), Assad in Syria; Kim Jong-Un in North Korea; Fernando Collor de Mello of Brazil; Augusto Pinoche of Chile; and Najib Razak of Malaysia etc.

Another major response to corruption in Nigeria, as in some Global South countries is the establishment of various Anti-corruption agencies. These include:

a. The Code of Conduct Bureau and the Code of Conduct Tribunal

b. The Independent Corrupt Practices and other related offences Commission (ICPC)

\section{c. Economic and Financial Crime Commission (EFCC)}

The members of the Code of Conduct Bureau were sworn in on 30 July, 1980 by Shagari with clearly defined functions which include:

a. To receive declaration of assets of public officers, made pursuant to the code of conduct;

b. To retain custody of such declarations and make them available for inspection by any citizen of Nigeria on such terms and conditions as the National Assembly may prescribe;

c. To examine the declaration and ensure that they comply with the requirement of the code of conduct and of any law for the time being in force (Agedah, 1993:16).

Despite the establishment of this bureau, and backed by the Code of Conduct Tribunal, little or nothing was achieved towards reducing, let alone eliminating the incidence of corruption in Nigeria. This is because public servants do not adhere to the tenets of the bureau.

The emergence of the Independent Corrupt Practices and other related offences Commission (ICPC) by the anti-corruption law of June 2000 during the chief Olusegun Obasanjo's civilian administration marked a new phase in combating corruption in Nigeria. However, the Commission commenced operation in September of 2000. Unlike past institutions set up in response to corruption in Nigeria, the ICPC was given relatively broad powers and mandates to enable it effectively and efficiently control corruption and other related offences in the country. In line with section 6 of the ICPC Act 2000 the Commission has the mandate to:

a. Where reasonable ground exists for suspecting that any person has conspired to commit or has attempted to commit or has committed an offence under this Act or any other law prohibiting corruption, to receive and investigate any report of the conspiracy to commit, attempt to commit or the commission of such offence and, in appropriate cases the offenders;

b. Examine the practices, system and procedures of public bodies and where, in the opinion of the Commission, such practices, systems or procedures aid or facilitate fraud or corruption, to direct and supervise a review; 
c. Instruct, advice and assist any officer, agency or parastatal on ways by which fraud or corruption may be eliminated or minimized by such officer, agency or parastatal;

d. Advise heads of public bodies of changes in practices, systems or procedures compatible with the effective discharge of the duties of the public bodies as the Commission thinks fit to reduce the likelihood or incidence of bribery, corruption, and related offences;

e. Educate the public on and against bribery, corruption and related offences;

f. Enlist and foster public support in combating corruption.

Considering the fact that the fight against corruption in Nigeria in the past was a pseudo one, and given the fact that the country had no convict on account of corrupt practices in a regular court, hence the hope that corruption would become history given the wide powers given to the ICPC. On implementing its mandate, the Commission charged 4 individuals to court for various acts of corruption in its first year of operation. By the end of its second year of operation, it charged 23 persons to court. This figure kept increasing so that towards the end of 2003, it rose to 49 persons. By 2006, it was 185 persons, and by October of 2008, the figure rose to 309. Correspondingly, it recovered N212million in 2005, N3.9 billion in 2006, and about N4.7 billion in 2007 from various financial criminals both in cash and assets. Enweremadu, (2011:8), revealed that:

The number of successful prosecutions (by the ICPC) from September 2000 to June 2006 was only two. The number only increased to 20 , in 2007, none of whom was a prominent figure. In other words, the ICPC could not translate all its efforts into tangible success. This dismal performance caused substantial discomfort among the populace and within the international community, giving room for further pressure on the government. This renewed pressure culminated in the establishment of the EFCC in April 2003.

The emergence of the Economic and Financial Crime Commission (EFCC), brought some improvement in response to corruption in Nigeria for two main reasons: the first being that the ICPC was constrained by the limitation in its establishment Act which provided that it can only investigate corrupt practices involving public officers, which also must be corrupt practices which occur after the Commission had come into existence and not before its emergence. Furthermore, the EFCC is endowed with wider powers and responsibilities which include conducting investigations of crimes of financial and economic magnitude (money laundering, advanced fee fraud, various forms of scam, bribery etc) within the public and private sector, as well as conduct arrest and prosecution of those indicted of the said offences. The second reason borders around their modus operandi. While the ICPC adopt a bottom-top approach in responding to corruption, the EFCC fancies a top-down approach, thus making the latter more confrontational in its approach. Despite these differences, both bodies seems to be more consistent and result-oriented as far as responding to corruption is concerned in Nigeria and have attracted the attention of other African leaders who sought for the agencies' expertise for their countries' anti-graft agencies, while it is a fact that Singapore can be said to be the starting point for the formation and institutionalization of modern anti-graft agencies in these areas, some of these agencies have been fashioned after those of Singapore( e.g. Independent Commission Against Corruption of Hong Kong (1974)); and the EFCC e.g. the Liberian AntiCorruption Commission as revealed by Sirleaf Johnson-the Liberian President (Nigerian Tribune, 2011:2) Consequently, these bodies (ICPC and EFCC), have been sustained by successive governments of Shehu Musa Yar'Adua, Goodluck Jonathan and presently that of Muhammadu Buhari. To strengthen the efforts of these agencies as well as widen the scope of fighting corruption, the Goodluck Jonathan's government in 2014 introduced what is referred to as Bank Verification Number (BVN) through the nation's apex bank-the Central Bank of Nigeria (CBN). A measure aimed at linking individuals by virtue of biometric identification to all the accounts they operate irrespective of names used on the account(s); the Buhari administration embarked on what it referred to as Treasury Single Account (TSA) in September of 2015 in order to effectively monitor the financial transactions of Ministries and Agencies in the country. Funny enough the Commercial banks which operated these accounts before the mandatory transfer to the said TSA to be managed by the apex bank transferred 22000 empty accounts contrary to expected 1.2 trillion naira (Emewu, 2015:3). The point being made is that in spite of the above desires and efforts of various 
administrations in Nigeria and those of several countries in the Global South towards combating corruption, the phenomenon has persisted. According Nnamdi Azikiwe in 1950 in Abyssinia, 'Nigeria is the key to the solution of the African problem' (Okocha, 2015:49). Thus if Nigeria gets it right in terms of tackling corruption, there is the possibility that the rest of Africa would get it right also. More so given the similarities in terms of characteristics of the sociopolitical and economic dynamics in the Global South countries, if Nigeria gets it right, the possibility of them getting it right also. Thus, the need to identify and examine the missing links towards effective management and control of corruption in Nigeria, Africa and indeed several countries in the Global South (using Nigeria as the research sample). This is so because; there exist some similarities with regards to the persistence of corruption in these areas despite efforts being made.

\section{THE MISSING LINKS TOWARDS EFFECTIVE MANAGEMENT AND CONTROL OF CORRUPTION IN NIGERIA, AFRICA AND SEVERAL GLOBAL SOUTH COUNTRIES}

This paper has carefully identified the missing links to effective management and control of corruption in Nigeria, Africa and indeed several Global South countries to a number of factors which include: corrupt individuals in the corridors of power; defective, or imbalance of political/social structure; legal justice; social justice; and international collaboration. We shall attempt a critical examination of these factors as they affect the persistence of corruption in these areas.

\section{CORRUPT INDIVIDUALS IN THE CORRIDORS OF POWER}

Perhaps, a major factor to effective management and control of corruption in Nigeria, Africa, and several Global South countries is the fact that the corridors of power in these areas (except few) are flooded by individuals who may have soiled themselves in one form of corrupt practice or the other or fraternizing with corrupt individual regarded as power elites. The case of Abarca, Mayor of Inguala (Guerrero) near Mexico, and his wife who were accused of master-minding the abduction and killing of about 43 students in 2014 stand as a perfect example. The outfall of corrupt individuals in the corridor of power is the fact that there will be lack of political will and moral justification on the part of these political leaders to stand up as saints to fight the menace in their various domains. Political leadership is highly correlated with the said individual's past. This is where countries in the Global North score very high which is why public officials resign on the slightest allegation of corruption on them. Yet political leaders (civilians or military) in Nigeria, Africa, and several Global South countries would prefer their citizens to close their eyes and keep mute over their past, but just accept them as messiahs and charismatic leaders anointed to deliver them from their myriad of socio-political and economic challenges. The point being made is that if Lee Kuan Yew was corrupt, it would have been difficult for him to transform Singapore from economic backward, unindustrialized and undeveloped country to developed and industrialized country (1959-1990); if Flight Lieutenant Jerry Rawlings was corrupt, he would not have enjoyed the massive support he had in his attempt at cleansing Ghana (1979-1981); Obasanjo in his inaugural speech on assumption of office as the Executive President of Nigeria on 29 May, 1999 stated that "one of the greatest tragedies of military rule in recent times is that corruption was allowed to grow unchallenged and unchecked even when it was glaring for everyone to see" (Siollum, 2008). Simply put that those with corrupt hands cannot fight the system they are part of (no wonder the existence of unremorseful avarice with regards to looting of public treasury; stashing of stolen wealth in the banks for their unborn generations while their citizens live like half-humans or sub-humans) these political actors are only reminded of their past if they fall out of favour with the elite class (local and international) with whom they had fraternized in time past. This is a missing link in the sense that some form of ideological hegemony is usually placed over citizens of these areas who easily accept the concession offered to them by these corrupt individuals through false or otherwise campaign promises or pseudo ideology. Thereby eyes are turned away, and mouth mute over past evils committed by these power elites whose ideas are considered the dominant idea at each point in time. In so far as this trend prevails, combating corruption in Nigeria, Africa, and several countries in the Global South would be a myth. It is worrisome when corrupt individuals are within the corridors of power. This is because integrity and credibility are put to question with regards to how likely they respond to their ugly past and effectively combat corruption.

\section{LEGAL SYSTEM}

Corruption has become so prevalent in Nigeria, Africa and several Global South countries to the extent that it has been recorded at both the Federal and State government levels; the executive, legislative and 
judicial arms of government. In Nigeria for example, the indictment of past state governors like Joshua Dariye, Jolly Nyame, James Ibori, SaminuTuraki; and a former police I.G., Tafa Balogun (Aiyetan, 2007:23-25; Adeyemo, and Yishau, 2007: 27; Onyechere, 2004:3$6)$; and various corruption scandals involving various legislative committees like the 3 million dollars bribery scandal involving Farouk Lawan Oil Subsidy Investigative Committee in 2012 of which about 620,000 dollars was alleged to have been collected by him (Farouk), the chairman, House of Representative investigating committee on oil subsidy, (Onyejena, 2012:18; Yusuf, 2012:6); the 10 billion naira scandal involving Dimeji Bankole - former Speaker, House of Representatives in 2011, (which he was later cleared of) Yusuf (2011:1\&2) the 44 million naira bribery allegation which led to the disbandment of the Herman Hambe led Capital Market Investigative Committee in 2012, Yusuf (2012:1); the claim by chief Esan Dangabar on trial of 32.8 billion naira fraud from the Police Pension Board that some Senators collected 8billion naira bribe from him; the 6.2 billion naira bribery scandal on the Elumelu-led House Committee on power reform in 2008 (Zero Tolerance, 2009:41), just to mention but a few. The above reveals the extent to which corruption has bedevilled the Nigerian state. This practice of 'national cake' sharing, that is, the culture of public corruption which was established by earlier civilian governments and entrenched by the military regimes, has been transformed into state policy Ibrahim (in Odekunle and Lame, 2000:76; Ekoiwak, 1986:87; Agedah, 1993:62). This has greatly affected the legal system in the country thus making them ineffective with regards to combating corruption. It is nothing but signs of decay in societies where corrupt individuals constitute part of the policy making process. Onyejena (2012:25) captured this sordid situation in the following words: "Perhaps one lesson here is that Nigeria is losing the fight against corruption. It has become so endemic and infections that you do not know who to trust anymore". While Malaysia hosted an International Conference against corruption in September of 2015 , its leaders were engulfed in embezzlement scandal at the same period; (in 2012, four prominent members of the ruling party in Ghanathe National Democratic Congress (NDC) were said to have been arrested on alleged corruption charges. These include: Alfred Agbesi Woyeome, Samuel Nerguaye Tetteh and his wife, and the Finance Ministry's legal Director. As a result of loss of focus and legitimacy due to corruption, legislative assemblies in Nigeria (both at the federal and state levels at different times in 2014 and 2015), India and other places have turned into arenas for free for all fight where expected law makers throw punches and wrestle each other as if they are in Madison square garden. Next is the fact that the legal institutions (the courts and anti-graft agencies) are confronted with pyramidal obstacles of meddling by the powers that be. These affect their operations negatively. What obtains under this circumstance is he who pays the piper dictates the tone. For example, the EFCC Act 2004, 2(3), and 3(2) states that:

The chairman and members of the Commission other than ex-officio members shall be appointed by the President and the appointment shall be subject to confirmation of the senate; $A$ member of the committee may at any time be removed by the President for inability to discharge the function of his office (whether arising from infirmity of mind or body or any other cause) or for misconduct or if the President is satisfied that it is not in the interest of the Commission or the interest of the public that the member should continue in office.

This no doubt played out in the removal of Farida Waziri as the EFCC chairman on $\left(23^{\text {rd }}\right.$ November, 2011)". ... there had been intense lobby especially from the House of Representatives and some highly influential politicians to get her out of office. The exspeaker Dimeji Bankole's case actually gave her a lot of trouble and at a point; she was in a dilemma" (Murphy, G., and Adetutu, F., 2011:6). Regrettably, on account of a petition by George Uboh to the Senate Committee on Ethics, Privileges and Public Petition, the immediate past EFCC boss, Ibrahim Lamorde is not smiling with members of the Senate on allegation of the Commission not properly accounting for over one trillion naira from monies retrieved from a former governor of Bayelsa State Alamieyeseigha and former Inspector General of Police, Tafa Balogun. Furthermore, there is the belief that the whole legal systems for managing corruption in Nigeria are themselves not absolutely corruption free thereby grappling with delivering legal justice as far as corruption is concerned. This is attributed to: selective prosecution of cases; delay in adjudication of corruption cases; politicization of their activities under the pretence of lack of evidences/substantial evidences to nail corrupt offenders (especially the sacred cows, untouchables, the power elites of the country) for example, it was in September of 2015 that the Code of 
Conduct Bureau (CCB) in its charge number $A B T / 01 / 15$, dated $11^{\text {th }}$ September filled before the Code of Conduct Tribunal (CCT) accusing the Senate President-Dr Bukola Saraki for what it termed anticipatory declaration of assets as well as false declaration of assets during his tenure as Kwara State governor and acquisition of assets beyond his legitimate earnings and operating of foreign accounts during the time as well as when he served in the senate, an action which is said to violate sections of the fifth schedule of the 1999 Nigeria Constitution (amended), and Section 2 of the CCB and CCT Act (Nwosu, 2015:6). The point being made is that where was the CCB and CCT all these years? What seen or unseen factor(s) is conditioning their action now? Whatever factor(s)in terms of freedom of information as well as political factor(s) which account for this delay may not be absent in other agencies for corruption management. This is evident on the number of high profile cases they have successfully secured conviction on since their inception, as well as invitation of individuals long after the period of their stewardship. In a recent demonstration embarked on by labour unions across the country, the judiciary was accused of aiding and abetting corruption by allegedly shielding corrupt public officials through granting perpetual injunction. The Union leadership considers these as widespread corruption in the judiciary (Omipidan et al. 2015:7). It is important to note that while some countries in Africa and the Global South have identified the fact that corruption prevails within the judiciary and are making efforts towards addressing it e.g. Ghanaian Judicial Council suspended about twenty two Judges for various corruption related offenses in September of 2015 based on Anas' revelation, others are still trying to phantom ways out of the ugly trend. For instance, while the President of the Nigerian Bar Association (NBA) Mr. Alegeh, condemn the attitude of judges in Nigeria who trade judgments for money, the Chief Justice of Nigeria (CJN) Justice Mahmud Mohammed challenged him to provide names of such judges for disciplinary measures (Tsa, 2015:8). This blame-game with regards to the uprightness or otherwise of the judiciary prevails in several Global South countries.

\section{SOCIAL JUSTICE AND SOCIO-POLITICAL IMBALANCE}

Social justice; and political/ social structure correlates as factors to corruption as well as the measures aimed at controlling it in Nigeria, Africa and in several Global South countries. These are the outfall of the degree of attachment and sentiments towards one's primordial or civic public, that is, the two public, as identified by (Ekeh, 1975) so that the definition of the civic public as amoral by individuals within it brings about the process of maximization of primitive accumulations by whatever means - corruption inclusive, in order to service and make strong the primordial public. While at the same time, those saddled with the responsibility of controlling corruption, do so on the basis of the above-mentioned attachment and sentiment to primordial factors. Therefore, what is considered corruption by a section of the public on the basis of their primordial difference with the actor(s) may largely be considered otherwise by the actor(s) and his/her primordial public since the said action(s) are considered on the basis of primordial sentiment(s). Since it is believed that a good citizen of the primordial public gives out and asks for nothing in return, a lucky citizen of the civic public gains from the civic public but enjoys escaping giving anything in return where possible. The said individual would not be considered a good fellow were he/she to channel all the said lucky gains to his/her private pocket. He/she would continuously be considered a good fellow only if he/she channels part of the largesse or proceeds from the civic public to the primordial public this also include making job available to people from his/her primordial public whether qualified or not to the detriment of others who may be more qualified. Primordial attachment here involves: religious, ethnic, and sectional sentiments; nepotism etc. With reference to Nigeria, the Comptroller-General of Immigration David Parradang was suspended in August 2015 for massively employing those that would best be considered as his primordial group members without recourse to the statutory guide for the said exercise. More so, the imbalance in the political and social structure of the nation which engenders mediocrity against merit provides the enabling environment for promoting primordial sentiments within the public sector. This imbalance is promoted through what is referred to as Federal Character. A policy which systematically blocks the entrance of some into the civil service no matter how qualified, and at the same time accommodates large number of others who have no business within the system, all in the name of federal character. Next to this is the fact that Nigeria is divided into six geopolitical zones. However, this imbalance is manifested in the number of States in each of these areas. While some have six states in their zone, others have seven states, yet others have five; with regards to representation especially in the Federal lower Chamber, some states have about three times the 
number of representation of some. According to (Alowes, 2015:52), 'Nigerian politics is built on a false bottom, a false foundation..." What prevails from the issues mentioned above is corruption of various degrees due to primordial attachment created by political and social imbalance.

In every facet of ordinary living in our society (Nigeria) today, we experience different patterns of corrupt practices. To get on to a job, for example, it is almost a rule that unless one knows someone in the establishment (or note(s)/ phone call(s) from powerful elite(s)) to push ones case through, the opportunity is as good as lost whether or not one is adequately qualified for selection...or ensuring that the less qualified applicant is selected through the influence of a god father in a position of power.... Political appointments and the distribution of political offices... are now invariably made not on merit but on the basis of favouritism (emanating from ethnocentrism, religious sentiment, sectionalism etc.). (Ejionye., and Emereuwaonu, 1986:274; emphasis, mine).

The outfall of these factors is that it is legal or legitimate to engage in brigandage of the civic public due to the socio-political imbalance in order to strengthen the primordial public. The ease at which corrupt public officials find safe-haven within their immediate communities which shields them and their sleazy wealth as well as the ease at which corrupt individuals in the country are adored and reverenced as power elites - scared and largely untouchable, as well as respected and conferred with various chieftaincy titles within and outside their immediate communities, as well as national awards is disturbing and no one seems to care (Dambazau, 2009:86; Wilmot, 2005:111-112; Agedah, 1993: 73-74; emphasis, mine). In responding to demonstrating labour unions calling for the heads of corrupt politician in the country in September 2015, the Secretary to the Government of the Federation, Babachir Lawal admonished the unionists "to walk their talk by first purging themselves of corrupt tendencies". In the same vein, the governor of Ekiti State Mr. Ayodele Fayose told the protesters to purge themselves of corruption before pointing fingers at politicians. Arguing that, no public office holder can successfully loot without assistance from civil servants. He thus described the nation-wide anti-corruption protest as mere jamboree, and the anti-corruption war of President Muhammadu Buhari as mere propaganda, asking him to probe how his campaign was funded (Omipidan et al., 2015:7). The fact remains that due to the absence of social justice (not jungle justice) conditioned by socio-political imbalance in Nigeria, Africa and several countries in the Global South, combating corruption would remain a mirage. A condition where members of given primordial group(s) protest of victimization of one of theirs by government, or insist that their corrupt member remains in power, and go as far as taking up arms in defence of these individuals (through military coup in some instances-Burkina Faso in September 2015, and the Democratic Republic of Congo 1994-2003 which claimed about five million lives; the drug war in Colombia 1970s till date), which sometimes results to ethno-religious conflict just to forestall arrest, investigation, prosecution, conviction; or retaliation of, or for their member(s) for corrupt practice(s) instead of given the individual up is a huge challenge to combating corruption. The socio-political structure of, China, and Japan made it that on conviction of corruption bordering on public fund, capital punishment largely follows due to lack of primordial sentiments; this is a missing link that must be addressed. This also explains the variation in public opinion in terms of how and who President Buhari should probe. While a section of the population subscribes to capital punishment, others prefer life imprisonment, yet others believe that public manual labour which they conceive as debasing and humiliating would serve as deterrence; again, while a section of the population subscribes to probing of the immediate past government of Goodluck Jonathan, others subscribes to probing all past Peoples Democratic Party (PDP) administrations starting with Obasanjo, yet others subscribes to probing all past administrations (military and civilian). These views are nothing but reflections of individuals' ambivalence in the definition of corruption as both acceptable and unacceptable anchored on primordial attachment. However, to keep the records straight, as well as bring sanity to the polity, the President should probe all past administrations in Nigeria with the hope and conviction that his administration would also be probed when his tenure winds off. The above (probity of past administrations not witch hunting) if institutionalized in these areas would restore probity and accountability in the Nigeria, Africa and indeed several Global South countries.

Due to the above discussed imbalance, the reward system in these areas (Nigeria in particular), fail 
woefully in rewarding hard work and honesty. Thus the use of whatever means available to make ends meet. Individuals due to negation of the principle of merit, move from point one to point one hundred of wealth in few months or years due to what is termed "connection" which is simply corrupt means. This ambivalence in the definition of corruption as both acceptable and unacceptable is what largely accounts for the kind of policy objectives and measures aimed at combating corruption in Nigeria, and several Global South areas and as such accounts largely for the inefficiency of anti-graft agencies in effectively combating corruption. This can be exemplified in the lack of public support for special courts for adjudication of corruption matters, as well as lack of support for effective laws on corruption and adequate powers and resources for these agencies. However with such renowned anti-corruption activists and academics like, Itse Sagay, Femi Odekunle, Etannibi Alemika etc in the Presidential advisory committee on corruption in Nigeria, the hope is that the most reasonable, effective and enduring solution would be adopted.

Singapore and a few other countries in the Global South were able to tackle these missing links, today, they are better off. The intentions may be right, but President Muhammadu Buhari, Sirleaf Johnson, John Mahama, Jacob Zuma, Park Geun-Hye of South Korea, Horacio Cartes of Paraguay, Ollanta Humala of Peru, and indeed all well- meaning leaders in the Global South must consider the above missing links for corruption to be effectively managed.

\section{INTERNATIONAL COLLABORATION}

Getting involved in corrupt practices by public officers would have been difficult if not almost impossible if there were no international collaboration for their immoral activities. The point being made is that developed economies of the world abate these corrupt individuals and their sleaze wealth by providing safehaven for lodging this stolen wealth; purchase of exquisite properties and other investments in so far as the said individual pays the required tax and worth have-you to the said bank and country where these wealth are hidden. One begins to wonder what the function of the International Court of Justice (ICJ) is, if it does not include in its schedule issues which border on preventing making lives of both living and unborn generation of citizens of a country hopeless due to act(s) of corruption. How is war crime? Or what is violation of human rights when people are made hopeless yet the ICJ leaves this serious issue to the host nation and the defrauded nation to settle through diplomatic and other means. The case of a former minister of transport (Umaru Dikko) during the second republic would not be easily forgotten by scholars of political history in Nigeria where the then military administration of Buhari, used both legal and extralegal means, in attempting to bring him (Dikko) back to Nigeria to face charges of corruption to the tune of about 4.4 million naira at the time, a situation which strained Nigeria-Britain relationship (Mpamah and Nwufo, 2014:263). Furthermore, it took Nigeria about 17 years to fully recover the Abacha loot from the Swiss bank. While on his first official visit to the US on his resumption of office (29 May, 2015) as the new Executive President of Nigeria, Muhammadu Buhari on his return from an official visit from the US in July 2015disclosed that the US is willing to assist Nigeria recover her stolen monies stashed in various banks in the US and other countries. According to him, the amount involved is over one 150 million dollars. While addressing world leaders in the UN's $70^{\text {th }}$ General Assembly, he admonished the international community to give serious consideration towards strengthening mechanisms for dismantling safe havens for corruption and urged member nations to do more towards returning stolen funds and assets to the defrauded countries. Noting corruption, cross border financial crimes, cyber-crime, and human trafficking as major challenges of the $21^{\text {st }}$ century which requires International Corporation to deal with (Obalonye, 2015), the question is why such stolen monies must be accepted by these countries in the first instance being fully aware that these public officers stole the said monies? At this age of advancement in information technology, why was the defrauded government not alerted over the said transactions? If the US could decline arms deal with Nigeria over what it termed violation of human rights by the Nigeria military in its fight against Boko Haram in 2014, and go as far as monitoring Nigeria's moves towards acquisition of these arms elsewhere, the same strategy should be applied towards tackling corruption in Nigeria, Africa, and indeed several Global South countries if the fight against corruption must be won. This is because corruption must not be considered anything short of gross violation of human rights that has the capacity of causing irreversible humanitarian crisis. This is not a denial of the successes recorded by anti-graft agencies through International Corporation towards repatriation of corrupt individuals who seek for refuge in other countries, or the dismissal of efforts made by various anti-graft agencies towards reduction of corruption in 
the Global South. For example, the effort made by the US agencies towards making Najib Razak of Malaysia face corruption inquiries in the US as reported by most US dailies on September $21^{\text {st }} 2015$; the trial and conviction in a London court of James lbori (one time governor of Delta State in Nigeria in April 2102); the arrest of one time Nigeria Petroleum Minister, Diezani Allison in October 2015 by the ICU in the UK on allegation of corruption involving money laundering just to mention a few.

\section{RECOMMENDATIONS}

Individuals with proven integrity should seek for elective political positions not political power merchants whose hands are full of corruption. This is important because it is only corruption free individuals that would have the political will, courage and moral justification to effectively combat corruption in these areas. Political events in the advanced polities in the Global North supports this view coupled with success of Lee Kuan Yew in Singapore. Very important is the fact that political leaders in these areas should resign on any allegation of corruption so as to provide enabling atmosphere for them to be investigated and prosecuted in line with existing laws.

There is need for the establishment of special court(s) which will help in no small measure in speeding up prosecution of corruption cases, as well as drastically reducing plea-bargain which characterize the regular courts. This will help in eliminating or at least reduce the obstacles posed by the existing unfriendly judicial process which militates against the efforts of anti-corruption agencies in combating corruption in Nigeria, Africa and several Global South countries and as such, make the agencies effective in prosecution of corruption cases. Very important is the fact that these legal systems for combating corruption must resist any political gladiator's attempt of meddling in their activities. The Anas' strategy in Ghana (2015) should be adopted for exposing these undesirable citizens (corrupt politicians seeking to influence the judicial process as well as the rotten elements within the judiciary) who constitute themselves into obstacles towards effective management and control of corruption in these areas.

There should be adequate measures on ground which will make the Freedom of Information Bill (FIB) function without hindrance. This will afford these agencies in charge of controlling corruption the power, opportunity, and strong mandate to seek for information from/on individual(s), group(s) suspected to have enriched themselves through corrupt means, as well as seek for explanations from both past and present public office holders and others living above their means. For example as required by section 7(1) of the EFCC 2004, Act. It is our belief that the fear and stigmatization of being culpable would reduce the incidents of corrupt practices in these areas especially among public officials.

As watchdogs of their nations, these anti-graft agencies should be part and parcel of the legislative process in their countries. This will afford them the opportunity to push forward bills that will help for the smooth running of their operations, as well as work assiduously towards repealing those legal provisions etc. which hinders their effectiveness in controlling corruption in their domains.

To effectively control corruption in Nigeria, Africa and Global South countries, there shall be no sacred cows. This means that the anti-corruption laws in these countries shall be above all. Therefore, section 308 of the 1999 Nigerian constitution (as obtained in some other countries) which shields chief executive through its immunity clause should be repealed if any meaningful progress is to be made towards reducing or eventual elimination of corrupt practice among public office holders. If the federal and state chief executives (the president, vice president, state governors, and deputy state governors), are arraigned before the law court while still in office on account of corruption and convicted, then other private and public office holders would become conscious of the fact that there are no sacred cows and as such, no place to hide when it comes to fighting corruption. If these clauses are expunged from these countries' constitutions, this would help in no small measure in removing impediments on the path of these anti-graft agencies, as well as assisting in reducing corruption to the barest minimum in these countries.

The core values of Nigeria, Africa, and several Global South countries must be redefined in line with the principle of merit, as well as upholding the right virtues. This would help in adjusting the social-political and economic structures of these areas in line with the global accepted best practices of equal opportunity for all irrespective of class, creed or ethnic affiliation. The above core value means that corruption is so conceived by all, as such would not be tolerated and condoned under religious, ethnic, sectional, or class sentiment. 
Nigeria, Africa and indeed all Global South countries should employ all necessary diplomatic measures towards making the UN pass a resolution of compulsory trial of these power elites by the ICJ for violation of human rights, as well as humanitarian crisis on their citizens brought about by their corrupt actions. While the continuous harmonious relationship between the anti-graft agencies in these areas and the International Financial Units (IFUs) is sustained. This has helped and shall continue to facilitate the activities of these agencies towards controlling corruption especially money laundering and other related financial crimes across national frontiers. Furthermore, a biometric data base which will enable these anti-graft agencies effectively monitor all financial transactions by individuals with their various financial institutions, as well as biometric capture of all financial transactions. This will make it difficult for monies to move across or within national frontiers illegally or unnoticed. This is what can be termed 'intensive and effective financial monitoring system' (IEFMS).

\section{REFERENCES}

Adeyemo, W. \& Yishau, O. (2007). From Power to Prison. Tell, July 30, pp.23-27. Lagos.

Agba, G. (2012). Nigeria Leads in Crude Oil Theft - Jonathan. Leadership, June 25, pp. 5.

Agbaje, O. (2012). EFCC: What next after Waziri. Daily Sun, November 24, pp. 7

Agedah, D. (1993). Corruption and stability of the third republic. Lagos: Perception Communications.

Aiyetan, D. (2007). From power to prison. Tell, July 30, pp. 23-27. Lagos.

Ajie, H \& Wokekoro, O. (2012). The impact of corruption on sustainable economic growth and development in Nigeria. International Journal of Economic Development Research and Investment, Vol. 3, No.1

Ake, C. (2003). Democracy and development in Africa. Ibadan: Spectrum Books Limited.

Akinkoye, O. (1986). Pathways to corruption in Nigeria: Corruption in development (pp. 92-95). The 1982 Proceeding of Nigerian Anthropological and Sociological Association, held in Zaria $10^{\text {th }}-13^{\text {th }}$ May. Edited by Odekunle, F. Ibadan: University Press.

Alli, Y. (2011). N6.18b Abacha loot recovered. The Nation. Retrieved from www.thenationolineng.net/2011/index... 20/06/2012.

Alowes, J.E. (2015). Of trust, votes and governance. Daily Sun. September 17pp52.

Anti-Corruption agency-Wikipedia the free encyclopaedia https://en.m.wikipedia.org/.../Anti-(No Date) Retrieved 25 $5^{\text {th }}$, September 2015.

Constitution of the federal republic of Nigeria (1999). Lagos: Federal Government Press.

Corruption in Ghana-Wikipedia the free encyclopaedia https://en.m.wikipaedia.org/.../corruption-

Corruption Perceptions Index: Transparency International Cpi. Tranprency.org/
Criminal Code Cap "C38", Economic and Financial Crime Commission Act with cases \& Materials (2010 Edition). Laws of the Federation, 2004. Princeton Publishing Company.

Edofolks-Gideon Orka's Memorial Speech-Edofolk. Com (No Date). Retrieved September 19, 2015 from Wikipedia the free encyclopaedia. www.edofolks.com/html/pub15htm

Economic and Financial Crimes Commission -EFCC- Executive--(No Date). Retrieved April 6, 2012 from Wikipedia the free encyclopaedia. www.efccnigeria.org.operations.html.

EFCC Hands over indicted Nigerian fraudster to United State. Saharareporters.com $>$ Home Retrieved 25/06/2012.

EFCC's Demand for a special court: A Dangerous Trend (No. Date). Retrieved April 20, 2012 from Wikipedia the free encyclopaedia. Elombah.com/index.php.

Ejionye, U. A \& Emereumaonu, E. U. (1986). Corruption as culture in Nigerian development: Corruption in development (pp. 274280). The 1982 Proceeding of Nigerian Anthropological and Sociological Association, held in Zaria $10^{\text {th }}-13^{\text {th }}$ May. Edited by Odekunle, F. Ibadan: University Press.

Ekeh, P. (1975). Colonialism and the two republics: A theoretical statement. Comparative Studies in Society and History, Vol. 17, No. 1. pp. 91-112. http://dx.doi.org/10.1017/S0010417500007659

Elite theory (No. Date). Retrieved April 8, 2012 from Wikipedia the free encyclopedia.en.wikipedia.org/wiki/elite-theory.

Emewu, I. (2015). TSA: CBN inherits empty accounts. Daily Sun. September $17 \mathrm{pp} 3$.

Enweremadu, D. U. (2011). Anti-corruption policies in Nigeria under Obasanjo and Yar'Adua: What to do after 2011?

Fabi, R. (2008). Nigeria President seeks end to immunity for leaders. Abuja (Reuters). Retrieved April 20, 2012 from Wikipedia, the free encyclopaedia.www. nairaland.com/206051/yaradua see...

Federal Ministry of Information (1994). Nigeria a viable black power: Economic development plans, programmes, policies \& projections. Lagos: Polcom Press.

Femia, E \& Joseph, V. (2006). Panel to political theory. London: Routledge.

Hamgbaba, O. A. (2007). Of national ethics and anti-corruption. Abuja: Project Edge Leadership retreat.

Ibori extradited to UK to face corruption charges www.transparencyng.com/index.php/au... Retrieved 25/06/2012

Igwe, S. C. (2010). How Africa underdeveloped Africa. Port Harcourt: Professional Printers \& Publishers.

Ikoiwak, E.A. (1986). Political office holders, bureaucrats and corruption in Nigeria: Corruption in development (pp. 82-91). The 1982 Proceeding of Nigerian Anthropological and Sociological Association, held in Zaria $10^{\text {th }}-13^{\text {th }}$ May. Edited by Odekunle, F. Ibadan: University Press.

Judicial reform Panel kicks against special court for EFCC, ICPC. (No. Date). Retrieved April20, 2012 from Wikipedia the free encyclopaedia. www.tribunal.coming/index.php/news/3...

Kazeem, O. (2015, October 6). Diezani, brothers to face trial for alleged bribery. The Nation, p. 1,6 \& 8 .

Kimberly, A., \& Elliot, E. (2010). Corruption as an International Policy Problem: Overview and Recommendations. The Peterson Institute for International Economics.

Mexico Among The World's Most Corrupt Nations in 2014 News...www.forbes.com/.../mexico-among-the-

Mohammed, A. S. (1986). Nepotism as a form of corruption, in Nigeria: Corruption in development (pp. 69-81). The 1982 Proceeding of Nigerian Anthropological and Sociological Association, held in Zaria 10th - 13 the May. Edited by Odekunle, F. Ibadan: University Press.

Money Laundery (prohibition) Act (2004). Explanatory memorandum. Abuja: Heritage Press Limited. 
Mpamah, A.C., and Nwufo, C.C. (2014). An examination of the privileges and immunities of diplomatic mission and their other members: A case of diplomatic lawlessness. Humanity, Jos Journal of General Studies. Vol. 7, No. 1.pp 263

Murphy, G., \& Adetutu, F. (2012). Why Farida Waziri was fired. Daily Sun, November 24pp.6.

Nanaghan, B. (2011). Leave the EFCC alone. National Mirror, November $9 . \quad$ Retrieved from http://www.mationalmirrorline.com

Newswatch Magazine - Nigeria still a very corrupt country www.newstachngr.com/index. php \% 3 fap... Retrieved 25/06/2012.

Nigeria - 10 years of transparency international monitoring... www.nigeriavillagesquare.com/articl...retrieved 25/06/2012.

Nigeria muse blog (2007, December $\left.25^{\text {th }}\right)$. Olusegun Obasanjo stole 2.4 trillion naira says CNPP Retrieved from www.nigeriamuse.com/offices/fraudwatch.

Nigerian Tribune. (2011). There'll be no sacred cow - Jonathan. September, pp 2-4.

Njoku, U. J. (2007).Corruption and social change in Nigerian public service and the agency-structure debate. Retrieved March 18, 2012 From Wikipedia, the free encyclopaedia www.hollerafrica.com $>$ Home.

Nwachukwu, C \& Alike, E. (2012). How N422bn was lost to Fuel Subsidy Fraud. Federal Government Committee Uncovers 17 infringements by Manseters. This Day, June 28pp. $1 \& 6$.

Nwosu, I. (2015). FG Charges Senate President. Daily sun. September 17, pp.6.

Obalonye, J.T. (2015, September 29). Dismantle safe havens for corrupt proceeds, Buhari urges world leaders. Daily Sun, p.7.

Odekunle, F. (1982). Nigeria: Corruption in development. Ibadan: University Press.

Odekunle, F., \& Lame, I. (2000). Fighting corruption and organized crime in Nigeria: Challenges for the new millennium. Ibadan: Spectrum Books.

Ogundele, K. (2012). EFCC charges Sylvia with N2.45bn fraud, The Nation, February, 25 pp. 5.

Ogundele, K. (2012). Court order assembly to disclose lawmakers' packages. The Nation, June 26, pp. 6.

Ojo, S. (2012). Waziri's 42 months in EFCC. Daily Sun, November 24, pp.7.

Okocha, E. (2015). I came to bury Ceasar, not topraise Zik...Daily Sun, September 23, pp 49.

Olakanmi \& Co (2006) Anti-corruption compendium. Abuja: Lawlords Publications.

Omipidan, I. et al. (2015:7). Labour in mass action over corruption: shuts down Abuja, other cities in support of anti-graft war. Daily Sun, September 11, pp.7.

Onyechere, I. (2004). High impact case studies of corruption and their lessons. Abuja: Ethics Resource Centre.

Onyejena, E. (2012). Disappointed by Farouk Lawan. This Day, June 2, pp. 18

Osoba, S. (1996). Corruption in Nigeria: Historical perspectives. Review of African Political Economy, Vol. 23, No. 69, pp. 371-386.

http://dx.doi.org/10.1080/03056249608704203
Our Milestone (2010). Anti-graft war: The impact is real. Nigeria's Economic and Financial Crimes Commission, Vol. 1, No. 1, May 2010.

Ribadu, N. (2004). Anti-corruption management. Abuja: Ethics Resource Centre.

Siollun, M. (2008). Nigeria's great speeches. The Home of Nigeria's History and Contemporary Affairs. Retrieved 3/25/2015 from https://maxsiollun.wordpress.com/great-speeches-innigerias-history/

Transparency International, 2012-Global Corruption Report. www.transpreancy.org $>$ home $>$ what we do $>$ research. Retrieved 5/09/2012

Transparency International, 2014-Global Corruption Report

Transparency International (2015). Corruption Perception Index 2014: Results. Retrieved September 29, 2015.

Tsa, G. (2015). Anti-graft war: CJN, NBA, divided over corrupt judges. Daily Sun, September 22, pp.8.

Umez, B. N. (2012). On the Fuel subsidy removal protests. The Punch, January 17, pp.16.

US agrees torecovernigeria's stolen money-The Sun Sunnewsonline.com/.../us-agrees-to-recov...(22 July 2015). Retrieved $2^{\text {nd }}$ October 2015.

Wilmot, P. (2005). Nigeria: The nightmare scenario interventions VI. Ibadan: Book Craft.

Wright-Mills, C. (1958). Structure of power in American society. British Journal of Sociology, 9(1). Retrieved from http://www.(sub.edu/- akabede/soc502mills2.pdf.

Yesufu, K., and Itua, F. (2015). 2015 budget: FG blows illegal N222b on subsidy. Daily Sun, September 23, pp.3.

Yusuf, A. (2011). EFCC detains Bankole after dramatic arrest: How N10b loan was shared by ex-speaker. The Nation, June 6 , pp. $1 \& 2$.

Yusuf, A. (2012, March 21). EFCC arrests OSOPADEC chairman over alleged $\mathrm{N} 61.63 \mathrm{~b}$ fraud. The Nation, p.6.

Yusuf, A. (2012). N4.56b 'fraud' trail: EFCC seizes ex-director's houses. Expansion director loses hotel, filing stations. The Nation, March 27,pp.1\&2.

Yusufu, A. (2012). ' $\$ 620,000$ Bribe': Lawan Set for Legal Battle. The Nation, June 26,pp.6.

Yusufu, A. (2012, March 22). N40m Bribe: House, Secallege Document Forgery. The Nation, pp. 1.

Zero Tolerance (2008). $5^{\text {th }}$ anniversary edition. The Magazine of Nigeria's Economic and Financial Crimes Commission, Vol. 3, No. 1, March.

Zero Tolerance (2009). Anti-corruption revolution Kick Off. The Magazine of Nigeria's Economic and Financial Crimes Commission, Vol. 4, No. 1, February

Zero Tolerance (2009). The new face of money laundering. The Magazine of Nigeria's Economic and Financial Crimes Commission, Vol. 4, No. 2, July

\section{DOI: http://dx.doi.org/10.6000/1929-4409.2016.05.03}

(c) 2016 Ethelbert Okey Lawrence; Licensee Lifescience Global.

This is an open access article licensed under the terms of the Creative Commons Attribution Non-Commercial License (http://creativecommons.org/licenses/by-nc/3.0/) which permits unrestricted, non-commercial use, distribution and reproduction in any medium, provided the work is properly cited. 